\title{
Głos nadziei w "erze świadectwa”. Kategoria świadka w dyskusji etycznej
}

DOI: http://dx.doi.org/10.12775/RF.2016.007

Świadectwa pełnią w ludzkim życiu doniosłą rolę, składane są w wielu sytuacjach, a z ich składaniem - w porządku prawnym, zawodowym czy kulturowym - wiąże się szereg sformalizowanych struktur i praktyk. Jak się wydaje, w ostatnich dekadach obserwować można zarówno rosnące zainteresowanie badaczy różnych dyscyplin problematyką świadectw, jak i rosnącą rolę samych świadectw i świadków w różnych aspektach życia. W świadomości zbiorowej czasy od zakończenia drugiej wojny światowej to okres szczególnego rozkwitu znaczenia świadków i świadectw. Nie brak obecnie instytucji, w których historycy, dziennikarze bądź wolontariusze poszukują „,świadków historii” i zbierają świadectwa dotyczące przeszłości. Swiadkowie - powiernicy prawdy, reprezentanci historii, bohaterowie demokracji, kreatorzy pamięci i przedstawiciele kultury - oddziałują na społeczną opinię i życie zbiorowości, poznając i przekazując prawdę, odkrywając wartości i podtrzymując pamięć o minionych wydarzeniach. Filozofia nie może pozostawać obojętną wobec istotnych i eksponowanych kategorii świadectwa i świadka.

O świadkach i świadectwach mówić można jako o specyficznych znakach naszych czasów. Shoshana Felman pisze o „erze świadectwa"1 , Anette Wieviorka o „erze świadka"2, a Jay Winter stwierdza, że „figura moralnego świadka jest ikoną boomu pamięci"’3. Avishai Mar-

1 S. Felman, In an Era of Testimony: Claude Lanzmann's Shoah, „Yale French Studies" 79 (1991), s. 39-81.

2 A. Wieviorka, The Era of the Witness, tłum. J. Stark, Cornell University Press, New York 2006.

3 J. Winter, The "moral witness" and the two world wars, "Ethnologie française", XXXVII, 2007, 3, s. 467. 
galit podkreśla, że liczne świadectwa są obecnie podstawowym i najistotniejszym źródłem naszej wiedzy. W wielu aspektach życia jesteśmy „złapani w sieć świadectw”, a nasze możliwości ich weryfikacji bywają ograniczone - w znacznej mierze skazani jesteśmy na zaufanie, osobiste poszukiwanie świadków-autorytetów i budowanie ich hierarchii ${ }^{4}$. Rzeczywistość świadectwa doceniał Józef Tischner, który pisał o łańcuchu świadectw, łączącym przeszłość, teraźniejszość i przyszłość w kolejnych aktach zawierzenia ${ }^{5}$. Warto $\mathrm{w}$ tym miejscu zwrócić uwagę na to, że mamy do czynienia z pewnym przewrotem w myśleniu o świadkach i świadectwach - na początku lat trzydziestych Gabriel Marcel pisał o degradacji pojęcia świadectwa, zniekształconego i sprowadzonego do instytucjonalnych form ${ }^{6}$.

W filozoficznej dyskusji często omawiany jest epistemiczny wymiar świadectwa7. W myśli należących do różnych szkół i tradycji filozoficznych autorów nie brak jednak także analiz uwzględniających jego wymiar moralny. Etyczna dyskusja o świadku jest bardzo zróżnicowana: przenika się w niej myśl chrześcijańska i żydowska, wątki personalistyczne i postmodernistyczne, hermeneutyczne i analityczne. Można wskazać na dwa jej główne nurty: francuską filozofię świadectwa, w dużej części zreferowaną polskiemu czytelnikowi przez Karola Tarnowskiego (należy w jej kontekście wymienić Marcela, Jeana Naberta, Emmanuela Levinasa, Paula Ricoeura, Jacquesa Derridę czy Jeana-Francoisa Lyotarda) oraz toczącą się obecnie anglojęzyczną debatę, w której świadek rozumiany jest jako przedstawiciel pamięci (jej przedstawicielami są Margalit czy Jeffrey Blustein). Interesujące wątki pojawiają się także w koncepcjach świadectwa proponowanych przez polskich myślicieli: wspomnianych już Tarnowskiego i Tischnera oraz Tadeusza Stycznia. Celem niniejszego tekstu jest przedstawienie świadka - w oparciu o analizy autorów, w myśli których świadectwo jest kategorią etyczną - jako podmiotu moralnego. $\mathrm{W}$ odpowiedzi na pytanie o to, kim jest świadek rozumiany jako podmiot moralny, pomoże skupienie się na konkretnych wątkach: zaangażowaniu świadka w proces świadectwa, religijnym zapośredniczeniu kategorii świadectwa, związku między świadectwem i doświadczeniem oraz między świadectwem a prawdą.

4 A. Margalit, The Ethics of Memory, Harvard University Press, Cambridge 2004, s. $179-181$.

5 J. Tischner, Myślenie według wartości, Kraków, Znak 1981, s. 349.

6 G. Marcel, Rozważania na temat wiary, w: idem, Być i mieć, tłum. P. Lubicz, PAX, Warszawa 1962, s. 251.

7 Zob. C.A.J. Coady, Testimony: A Philosophical Study, Oxford University Press, New York 1992. 


\section{Zaangażowany świadek w refleksji etycznej}

Możliwość dawania świadectwa, przekazywania innym swoich osobistych, często trudnych doświadczeń jest charakterystyczna wyłącznie dla ludzi ${ }^{8}$. Wyróżnia nas ze świata zwierząt, wskazując zarówno na wyjątkowość ludzkiego, świadomie przeżywanego cierpienia jak i międzyludzkiej komunikacji. Można za Marcelem zapytać, czy istota człowieka nie polega właśnie na możliwości świadczenia9. Dawanie świadectwa - ów specyficznie ludzki fenomen - to świadomy akt illokucyjny, który może być spełniony pod określonymi warunkami ${ }^{10}$. W fenomenie świadectwa musi być więc obecnych kilka elementów: podmiot - osoba świadka, konkretna treść, przebiegający w czasie akt świadectwa oraz jego odbiorca czy odbiorcy ${ }^{11}$. Świadek przekazuje innym treść swojego osobistego doświadczenia, które jawi mu się jako ważne. Czuje, że w pewnym sensie jest kimś szczególnym i niezastępowalnym, gdyż ciąży na nim imperatyw ujawnienia dostępnej mu prawdy ${ }^{12}$. Wobec pewnych wydarzeń nie może zostać obojętny, angażują go one i zmieniają jego życie. Dając świadectwo podmiot posługuje się własna, nieuchronnie subiektywna, niedoskonałą i ulotną pamięcią tak, aby pewne szczególnie ważne treści uczynić własnością wspólnoty, częścią wspólnej narracji. Prywatna sfera doświadczeń podmiotu, często bardzo osobistych, przeniesiona zostaje $\mathrm{w}$ sferę publiczną. Istotne dla rzeczywistości świadczenia jest obecne $\mathrm{w}$ nim zobowiązanie do pamiętania i podtrzymywania pamięci o tym, co prawdziwe, ale nieznane, przemilczane, a czasem zakłamywane i niechciane ${ }^{13}$. Autorzy zajmujący się moralnym wymiarem pamięci postrzegają świadka jako łącznika między sferą pamięcią indywidualnej i zbiorowej, który odtwarzając własne wspomnienia i nadając im kształt, równocześnie kształtuje przez nie innych - bezpośrednich odbiorców, a w wielu przypadkach także przyszłe pokolenia. Świadectwo niejako ze swej natury wiąże przeszłość i przyszłość, przesłanie dla nieokreślonej jeszcze przyszłości z subiektywną pamięcią o przeszłości ${ }^{14}$.

Sytuacja dawania świadectwa jest w sposób konieczny dwustronna, dialogiczna. Grono jego odbiorców może być kameralne bądź liczne,

8 J.-F. Lyotard, The Differend: Phrases in Dispute, tłum. G. Van Den Abbeele, University of Minessota Press, Mineapolis 2002, s. 28.

9 G. Marcel, Dziennik metafizyczny, w: idem, Być i mieć, s. 114.

10 A. Frish, The Ethics of Testimony: A Geneological Perspective, "Discourse” 25.1\&2 (2003) , s. 36; C.A.J. Coady, Testimony: A Philosophical Study, s. 25.

11 K. Tarnowski, Podmiot jako świadek, w: idem, Wiara i myślenie, Znak, Kraków 1999, s. 18.

12 Ibidem, s. 60.

13 A. Margalit, The Ethics of Memory, s. 159.

14 Ibidem. 
świadectwo może zostać przekazane jedynie bliskim, bądź może stać się częścią publicznej debaty. Świadectwo służy nie tylko do przekazania informacji czy wiedzy, ale także do wydawania sądu - na podstawie relacji świadka, odbiorca wyrabia sobie zdanie o danym zdarzeniu czy sekwencji zdarzeń, motywach czynu, charakterze sprawcy ${ }^{15}$. Szczególnie czytelną sytuacją świadczenia, w której łatwo jest wskazać na konkretnych odbiorców jest formalne składanie zeznań, kiedy świadek staje przed sądem, ławą przysięgłych czy powołaną do oceny danego wydarzenia komisją.

Sama idea świadectwa zakłada posiadanie przez świadka unikalnej wiedzy czy doświadczenia. Lyotard nazywa świadka adresatem narzucającej się frazy rzeczywistości ${ }^{16}$. Świadek posiada szczególną perspektywę, niejako uprzywilejowany dostęp do rzeczywistości. Dysponuje doświadczeniem „z pierwszej ręki” - unikalnym, niedostępnym dla innych, $\mathrm{w}$ pewnym sensie prestiżowym ${ }^{17}$. Przysługuje mu szczególny rodzaj autorytetu epistemicznego i moralnego. Filozofowie zajmujący się rzeczywistością świadczenia przyznają świadkowi szczególny moralny status, wynikający z posiadania pierwszoosobowej perspektywy, niepowtarzalnego doświadczenia, bądź zaangażowania i osobistego stosunku do treści świadectwa. Ów stosunek do opisywanych wydarzeń jest niezwykle ważny - stanowić może pewną gwarancję słuszności oceny relacjonowanych wydarzeń, nie pozwala ich bagatelizować, umniejszać zła, dopuszczać niesprawiedliwości. Ważnymi motywami dawania świadectwa są potrzeba właściwego osądzenia wydarzeń i ich sprawców, a także przestrzeganie przed powielaniem w przyszłości tego co złe i pragnienie upamiętnienia oraz upowszechniania tego, co dobre. Świadczeniu towarzyszy oczekiwanie na pewne reakcje wspólnoty, podzielenie przedstawianego przez świadka osądu wydarzeńn ${ }^{18}$. Ciekawą cechą tej dyskusji jest obecna u wielu autorów, niemal programowa rezygnacja z przypisywanej tradycyjnie świadkom kategorii bezstronności. Świadek interesujący z punktu widzenia etyki to nie obserwator starający się obiektywizować swoje doświadczenia, aby odtworzyć je w możliwie najdokładniejszy sposób, ale przede wszystkim człowiek

15 J. Blustein, The Moral Demands of Memory, Cambridge University Press, New York 2008, s. 336-337.

16 F. Lyotard, The Differend: Phrases in Dispute, s. 45.

17 Wśród zajmujących się tym zagadnieniem autorów nie ma pełnej zgody co do tego, czy doświadczenie „z pierwszej ręki” utożsamiać należy z doświadczeniem naocznym; o braku konieczności naoczności doświadczenia pisze C.A.J. Coady, a także A. Frisch. Margalit natomiast broni kategorii naoczności, tłumacząc, że stanowi ona gwarant bezpośredniości i autentyczności wiedzy świadka (zob. C.A.J.Coady, Testimony: A Philosophical Study, s. 27; A. Frish, The Ethics of Testimony: A Genealogical Perspective, s. 36; A. Margalit, The Ethics of Memory, s. 172-173).

18 Ibidem, s. 336-337. 
zaangażowany po konkretnej stronie, oceniający i pewny słuszności swej oceny, patrzący na opisywane wydarzenia z własnego punktu widzenia, przez pryzmat osobistych przeżyć.

Dawanie świadectwa ma służyć przekazywaniu prawdy czy wiedzy, ale też uwrażliwieniu innych na czyjąś krzywdę, dokonywaniu i prezentowanie moralnej oceny czynu, przestrzeganiu drugich przed określonym sposobem postępowania (bądź czasem - jak w przypadku rzadko analizowanych świadectw o czynach chwalebnych - zachęta do niego). Zbiorowość nie zawsze jest do świadków nastawiona życzliwie, nie w każdym wypadku znaleźć można przychylne, chętne ich wysłuchania audytorium, nie zawsze też istnieje możliwość swobodnego dzielenia się doświadczeniami. Gdy bezpośrednie dzielenie się świadectwem jest niemożliwe, świadectwo może być spisywane, czy też po prostu pielęgnowane w pamięci na przyszłość, kierowane (niekoniecznie wprost) do przyszłych pokoleń. Można mówić także o świadectwie mającym postać inną niż narracyjna - świadectwo można dawać swoim życiem, wiernością wartościom i ideałom czy obowiązkom ${ }^{19}$.

Tarnowski opisuje świadectwo jako doświadczenie kształtujące podmiotowość - oto świadek wezwany zostaje do wyjawienia czegoś, co się wydarzyło. Stało się coś ważnego, często złego - miała miejsce krzywda, okaleczone bądź zniszczone zostało czyjeś życie. Wezwanie do zaświadczenia o tym, co się stało jest w pierwszej kolejności wezwaniem do świadczenia wobec poszukujących prawdy bliskich osoby skrzywdzonej. Ważne wydarzenie domaga się wydobycia na jaw i oddania sprawiedliwości temu, co istotne. Jest to możliwe jedynie w konkretnym świadectwie ${ }^{20}$. Imperatyw świadczenia „budzi" podmiot, wyrywa go o ile ten zdecyduje się go przyjąć - z bierności i relatywizmu. Podmiot obudzony angażuje się i staje świadkiem krytycznym, przyjmującym odpowiedzialność, ale i samodzielnie poszukującym dalszej wiedzy, formułującym krytyczną opinię. Świadek krytyczny ma docierać do różnych źródeł, tak, aby osiągnąć maksymalny poziom kompetencji. Wyraźnie obecny jest tu moment wolności i decyzji - podmiot może się wycofać, odrzucić wezwanie do świadczenia, ciąży jednak na nim (jako na tym, który był obecny i którego nie można zastąpić) szczególna odpowiedzialność. Sytuacja świadka jest zawsze indywidualna i wyjątkowa, swoiście niedookreślona. Stanowi okazję do samopotwierdzenia, zarazem rodzi pokusę koncentracji na sobie, ale też zaprasza do „wyjścia z siebie", skupienia na prawdzie wraz z jednoczesnym zapomnieniem o sobie ${ }^{21}$.

19 J. Blustein, The Moral Demands of Memory, s. 327.

20 K. Tarnowski, Podmiot jako świadek, s. 15-17.

${ }^{21}$ Ibidem, s. 18-20. 
Ricoeur uznawał świadectwo za fenomen złożony i skłaniający do refleksji, bliski symbolowi, ale $\mathrm{w}$ odróżnieniu od niego posiadający konkretną treść. Oparte na relacjonowaniu tego, co się widziało bądź słyszało świadectwo ma sens quasi-empiryczny. Zakorzenione jest w rzeczywistości, ale się w niej nie wyczerpuje - jego istotą jest nie samo doświadczenie, ale narracja, dzięki której coś widzianego przeniesione zostaje na płaszczyznę wypowiedzianą. Autor umieszcza świadectwo w sytuacji dyskursu, procesie, w którym świadek musi opowiedzieć się po którejś ze stron. Dąży do uzasadnienia jakiegoś stwierdzenia, dzięki opowieści prowadząc do jego sensu wychodzącego poza naoczny charakter relacjonowanego doświadczenia ${ }^{22}$.

W koncepcji Blusteina dawanie świadectwa stanowi wyraz cnoty zatroskania, skupienia na cierpieniu, zawsze konkretnym i dotykającym konkretnej osoby. Okolicznościami, które w sposób szczególny nawołują do dawania świadectwa są cierpienie, trauma, zagrożenia życia czy bliskość śmierci ${ }^{23}$. Marcel pisał w podobnym kontekście, że wielcy świadkowie nie rekrutują się spośród szczęśliwych, ale spośród cierpiących i prześladowanych ${ }^{24}$. Paradygmatycznym przykładem dawania świadectwa jest dla autorów świadczenie o złu, krzywdzie i cierpieniu, prawdopodobnie dlatego, że krzywda szczególnie dobitnie woła o sprawiedliwość. Autorzy uznają że najdobitniejsza wydaje się potrzeba świadczenia o złu radykalnym - największych zbrodniach dokonywanych na skalę masową. Świadectwa o największych zbrodniach wiązać się mają z imperatywem pamięci jako przestroga na przyszłośćc ${ }^{25}$. Moralna wartość dawania świadectwa wynika, zdaniem Blusteina, z głębokiego wewnętrznego związku z dobrem i złem. Świadek staje wobec dobra lub zła i odpowiednio na nie reaguje, wciela w życie dobro i sprzeciwia się złu. Do dawania świadectwa wzywa wspólnota człowieczeństwa, szczególnie dobitnie ujawniająca się właśnie w kontekście cierpienia i nieszczęścia. Motywem świadczenia o dobru bądź złu może być też poczucie solidarności z drugim ${ }^{26}$.

Bycie ofiarą ma w sposób szczególny predestynować do dawania świadectwa, sprzyjać posiadaniu właściwej perspektywy i wydaniu słusznej oceny ${ }^{27}$. Nie każde świadectwo musi mieć realny wpływ na przyszłe wydarzenia - możliwa jest sytuacja, w której za świadczeniem nie pójdą żadne zmiany $\mathrm{w}$ świecie, pozostanie ono symboliczną

22 P. Ricoeur, Hermeneutyka świadectwa, w: Nazwać Boga. Teksty Paula Ricoeura, red. R. Grzywacz, tłum. R. Grzywacz, WAM, Kraków 2011, s. 18-20.

${ }_{23}$ J. Blustein, The Moral Demands of Memory, s. 336.

24 G. Marcel, Rozważania na temat wiary, s. 253.

25 J. Blustein, The Moral Demands of Memory , s. 324-327; J. Tischner, Myślenie według wartości, s. 348-352.

26 J. Blustein, The Moral Demands of Memory, s. 321-322.

27 Ibidem, s. 319. 
afirmacją dobra bądź sprzeciwem wobec zła ${ }^{28}$. Świadectwo takie, choć nie przynosi oczekiwanych owoców, pozostaje moralnie wartościowe. W ograniczonych warunkach działania, gdy ludzkie możliwości ingerencji w świat okazują się niewielkie, złożenie świadectwa, w którym jasno określona jest moralna orientacja podmiotu, okazać się może najlepszym możliwym sposobem działania.

Specjalna kategoria świadka - świadek moralny, szczególnie interesujący z punktu widzenia etyki przedstawiciel pamięci zbiorowej, pojawia się w koncepcji Margalita. Za jego wzorcowy przykład autor uznaje ofiarę moralnego zła, choćby niesprawiedliwego reżimu. Z grona innych świadków, moralnego wyróżnia unikalne, osobiste doświadczenie cierpienia spowodowanego moralnym, zawinionym przez kogoś złem. Dla bycia tego typu świadkiem kluczowa jest, jak pisze Margalit, kombinacja zła i cierpienia. Autor wyklucza z grona świadków moralnych osoby dzielące się doświadczeniem zła naturalnego, kataklizmów czy katastrof, a także te, które osobiście, „z pierwszej ręki” nie doświadczyły cierpienia wskutek zła i niesprawiedliwości (nawet jeśli były ich zamierzonym celem). Zgadza się jednak, by w pewnych wypadkach uznawać za świadków moralnych bezpośrednio zaangażowanych obserwatorów, pełniących szczególne role - na przykład działaczy akcji pomocowych czy korespondentów wojennych - o ile ich działanie powodowane jest pobudkami moralnymi. Moralny cel działania jest podstawowym warunkiem, jaki spełniać musi świadek zasługujący na miano moralnego. Dodatkowo taki świadek winien znajdować się w sytuacji ryzyka: zarówno "ryzyka ofiary”, związanego z przynależnością do zbiorowości, przeciw której wyrządzane jest zło, jak i świadomie podejmowanego "ryzyka świadka”, starającego się dokumentować wydarzenia, które są jego udziałem, aby móc przekazać wiedzę o nich w przyszłości. Specyficznym spoczywającym na moralnym świadku wymogiem jest takie sformułowanie komunikatu, by był on czytelny dla odbiorców. Przed świadkiem dzielącym się doświadczeniem niewyobrażalnego zła postawione jest niezwykle trudne zadanie - ma on mówić o tym, co nie daje się nazwać, opisać za pomocą słów, co wymyka się językowi ${ }^{29}$.

Dla moralnego świadka konieczna jest według Margalita nadzieja na przywrócenie porządku, nastanie wspólnoty, która wysłucha świadectwa i dokona właściwej oceny przedstawionych wydarzeń. To nadzieja, że siła zła, nawet wielkiego, ostatecznie okaże się ograniczona. W obliczu burzącej moralny porządek niesprawiedliwości, nadzieja taka ma w sobie coś heroicznego. Nadzieja świadka może być słaba, daleka od pewności, żywiona wbrew przewidywaniom i prawdopodobieństwu. Minimalny poziom nadziei, jaki zdaniem autora musi towarzyszyć

28 Ibidem, s. 336.

29 A. Margalit, The Ethics of Memory, s. 164-165. 
świadkowi, to nadzieja na własną przyszłość, na ciągłość własnego ja, w którego pamięci przetrwają minione wydarzenia ${ }^{30}$.

Z zaprezentowanych analiz wyłania się postać świadka świadomego, krytycznego, dokonującego moralnej oceny i przyjmującego odpowiedzialność. Można w tym kontekście mówić o świadku zaangażowany $m$, przy czym pamiętać trzeba, że zaangażowanie jest w pewnym stopniu konieczną cechą każdego świadka. W bodaj najpowszechniejszym, jurydycznym kontekście, świadek jest powołany, ma obowiązek składania zeznań i mówienia prawdy, za co ponosi odpowiedzialność, a treść jego świadectwa może mieć wpływ na wyrok sądu czy losy innych ludzi. Świadek sądowy w pewnym sensie opowiada się po którejś ze stron procesu. A jednak zaangażowanie świadka moralnego czy krytycznego wydaje się sięgać znacznie dalej - sam stara się podtrzymywać swoją pamięć i pogłębiać wiedzę o danym wydarzeniu, znaleźć odpowiednie audytorium, odpowiednio ukształtować i zaprezentować świadectwo. Jest aktywnym uczestnikiem czy wręcz inicjatorem dialogu, nie tylko stroną przesłuchiwaną. Jest odpowiedzialny za właściwą ocenę wydarzeń, którą ma przekazać innym. Świadek taki musi przezwyciężyć własne cierpienie i kierować się wyjątkowa, heroiczną nadzieja, nie tracąc wiary w ostateczne zwycięstwo dobra i sprawiedliwości. Zaangażowanie świadka, nierzadko prowadzące do poświęceń, jest zaangażowaniem moralnym, podjęciem szczególnie ważkiej misji głoszenia świadectwa.

\section{Od duchowości do moralności; od absolutnego świadka do drugiego człowieka}

Kategoria świadectwa niewątpliwie zakorzeniona jest w myśleniu religijnym. W etycznej dyskusji o roli i zadaniach świadków pojawiają się nierzadko odniesienia do wymiaru nadprzyrodzonego, a autorzy po wielekroć odwołują się w niej do religijnych kategorii, takich jak męczennicy czy święci. Jednocześnie tej filozoficznej refleksji nie sposób sprowadzać do konkretnej religii - mowa tu raczej o absolucie, pragnieniu absolutu czy absolutnym świadku niż o Bogu osobowym. Większy nacisk niż na ściśle rozumiane życie duchowe kładziony jest na poszukiwanie prawdy i wyjście ku innym. Analizy nadprzyrodzonego zapośredniczenia rzeczywistości świadectwa okazują się interesujące także z punktu widzenia moralności.

Ricoeur, rozpoczynając analizy kategorii świadectwa pisał, że jest ona problemem filozoficznym wyłącznie w takiej filozofii, w której

30 Ibidem, s. 162. 
sens ma zagadnienie absolutu. Świadectwo, które ma wykraczać poza porządek prawny czy historyczny, poza jednostkową opowieść, które stosuje się do słów dzieł, działań, całości życia, które przekracza ludzkie doświadczenie i historię, jest świadectwem o absolucie - zawarty jest w nim element doświadczenia absolutu. Wymóg absolutu sprowadzony zostaje do zgłębienia aktu immanentnego w stosunku do każdego ludzkiego działania. Filozofia, w której mieści się pojęcie świadectwa musi, podobnie jak samo świadectwo, umożliwiać wzniesienie się świadomości do transcendencji ${ }^{31}$.

Pewną nieuchwytną i niewyjaśnioną podstawę metafizyczną świadectwa, tkwiącą w pierwiastku religijnym, dostrzegał Marcel. Rzeczywistość świadectwa wiązał z wiarą i wiernością̧2. Pierwsza z nich polega na bezustannym poświadczaniu, natomiast druga to powtarzane świadectwo, chronione przed możliwością zatarcia ${ }^{33}$. Wierność może się odnosić wyłącznie do osoby, nie do idei czy ideału. W porządku świadectwa konieczny jest element wierności osobie - nie tylko drugiemu człowiekowi, ale także absolutnej osobie, absolutnemu ty, które może wzywać i brać na świadka. Świadectwo w rozumieniu Marcela jest nierozerwalnie związane z porządkiem wiary, niekoniecznie rozumianej ściśle religijnie - także jako wiary, której „doświadczamy wszędzie, przede wszystkim w nas samych" ${ }^{\prime 4}$. Wartość duchowa świadectwa staje się jednak szczególnie wyraźna wówczas, gdy dotyczy ono rzeczywistości niewidzialnych, nienarzucających się z dosłownością doświadczenia zmysłowego. Dla Marcela fascynująca jest potrzeba istnienia świadka poświadczającego rzeczywistości wyższe, ku którym kieruje się religijny wymiar świadectwa - w zetknięciu z porządkiem absolutu, konieczny okazuje się człowiek wierzący - świadek nieproporcjonalnie skromny i słaby ${ }^{35}$. Podmiot poszukujący prawdy i spełnienia, zostaje "wezwany jako wezwany". Zdaje sobie sprawę z tego, że w jego głębi tkwi coś innego, "bardziej wewnętrznego" niż on sam. Odkrywa absolutną wolę, którą należy odczytać i absolutną rzeczywistość domagającą się afirma$\mathrm{cji}^{36}$. Ostatecznie afirmacja rzeczywistości absolutnej niejako rozgrywa się w podmiocie - Marcel pisze o niej, że „raczej nią jestem niż wypowiadam, jestem raczej jej siedliskiem niż podmiotem"37.

W dokonywanej rekonstrukcji analiz Marcela, Tarnowski zwraca uwagę na punkt wyjścia, z którego podmiot zaczyna poszukiwania abso-

31 P. Ricoeur, Hermeneutyka świadectwa, s. 15-16.

32 G. Marcel, Dziennik metafizyczny, s. 112-114.

33 Ibidem, s. 113; tegoż, Rozważania na temat wiary, s. 252.

34 G. Marcel, Dziennik metafizyczny, s. 114-117.

35 G. Marcel, Rozważania na temat wiary, s. 252.

36 G. Marcel, Dziennik metafizyczny, s. 147-165.

37 G. Marcel, Zarys fenomenologii posiadania, w: idem, Być i mieć, s. 203. 
lutnego świadka - człowiek pragnie poznać prawdę o samym sobie, jest pewien jej istnienia, uświadamia więc sobie istnienie kogoś, kto tę prawdę zna. Poszukuje odpowiedniego partnera do dialogu, który mógłby skierować ku niemu wezwanie. Zwracając się ku absolutnemu świadkowi, dokonuje elementarnego aktu wiary, „zwraca się ku..." całym soba, sam kieruje do niego wezwanie, najbardziej rzeczywisty z możliwych apeli. Absolutny świadek - wyjątkowy, całkowicie odrębny od innych partner dialogu, bardziej wewnętrzny niż wnętrze podmiotu, wyłania się z głębi tajemnicy ontologicznej, z wnętrza ludzkiego „ja” w odpowiedzi na pytanie o prawdę i na poczucie rozdarcia między własną ludzką godnością, a indywidualną niezgodnością. Umożliwia przemianę ludzkiego pragnienia i poszukiwania w wezwanie, samemu uprzednio się objawiając, kierując ku podmiotowi pierwsze wezwanie - najbardziej wewnętrzne w stosunku do podmiotu „wezwanie jak wezwanie ${ }^{38 "}$.

Podobną genezę potrzeby zakorzenionego religijnie świadectwa dostrzec można w filozofii Naberta. Podmiotowość - ja - rozdarta jest między poczuciem braku satysfakcji, własnej słabości, „niesprostania”, a przenikającym ją doświadczeniem absolutu, swoistym świadectwem absolutu w głębi ja. Podmiotowość zostaje obudzona, przeniknięta absolutem, który sam się w niej afirmuje, zarazem jednak ciągle jest obecne w niej i w otaczającym ją świecie niemożliwe do pokonania radykalne zło $^{39}$. Ludzkie ja, stając wobec aktu pierwotnej afirmacji, doświadcza największej wyzwalającej pewności. Odkrywa nie-byt: własną słabość, samotność, winę, ograniczenie, zarazem jednak doświadcza niezwykłej pewności, niepozwalającej mu w siebie zwątpić. To pewność więzi $\mathrm{z}$ pierwotną afirmacją $\mathrm{w}$ nim się właśnie afirmującą. Jej inicjatywa wyzwala ja, które staje się samo dla siebie przedmiotem refleksji i bierze w posiadanie swoją świadomość. Akt jego refleksji jest transcendowany, przeniknięty przez pierwotną afirmację - „działanie, które go przekracza i ustanawia". W powiedzeniu ,ja jestem” objawia się najwyższa pewność i wezwanie - świadomość afirmująca i afirmowana stanowią jedno. Wraz z nimi objawia się pewność i wymóg prawdy i dobra, sprzęgnięte zostają wymiar egzystencjalny, moralny i religijny. Podejmujące refleksję nad samym sobą ja zostaje odesłane do świata, aby urzeczywistniać $\mathrm{W}$ nim pierwotną afirmację $e^{40}$. W pierwotnej afirmacji ujawnia się absolut będący pragnieniem Boga. Boskość - idealny wymiar świadomości, ujawniające się w akcie ja czyste, to, co ostatecznie wiedzie do Boga - może pojawić się w świecie jako „zaskakujące świadectwo absolutnego świadka" - w aktach podmiotu uznawanego za świadka.

38 K. Tarnowski, W poszukiwaniu absolutnego Świadka, w: idem, Wiara i myślenie, s. $138-144$.

39 Ibidem, s. 23.

40 T. Gadacz, Historia filozofii XX wieku, t. 1, Znak, Kraków 2009, s. 348-350. 
Boskość - aprioryczna, normatywna i obiektywna - jest idea, którą człowiek może odkrywać i której może dawać, zawsze niedoskonałe, świadectwo. Idea czyni możliwym poznanie boskości w doświadczeniu, o którym można dawać świadectwo, tymczasem realność świadectwa odnawia tę ideę i czyni ją głębsząa ${ }^{41}$. W pierwotnej afirmacji podmiotowość zostaje obudzona, przeniknięta absolutem, który sam się w niej afirmuje, jednak obecne $\mathrm{w}$ człowieku i w świecie radykalne zło - to, co nieusprawiedliwione nadal ją przytłacza. Afirmujący się w niej absolut jest doświadczany, ale zarazem pozbawiony realności i ontologicznej gęstości. Ja potrzebuje kogoś, kto zaświadczy o realności absolutu. Ludzki podmiot, który doświadczył w sobie pierwotnej afirmacji poszukuje świadków - znaków, przez których absolut objawi się jako rzeczywisty. Nabertowskimi „znakami absolutu” są święci ${ }^{42}$.

W myśli Levinasa najbardziej podstawowe ze świadectw: „oto jestem" to wyznanie ja naznaczonego trauma, prześladowanego, wyzutego ze swej władczej podmiotowości, a zarazem objawienie się i część chwały nieskończoności. Ja wraca do „oto jestem” w przejrzystości, której nie zakłócają mroczne przestrzenie krzywdy i winy, daje nieskończoności świadectwo, które nie upraszcza i nie tematyzuje, którego prawda nie jest oczywistością. Levinasowskie świadectwo to coś w ludzkim życiu absolutnie wyjątkowego, „,z niczym nieporównywalna struktura, nieredukowalny do przedstawienia wyjątek od reguły bycia", sposób „dziania się Nieskończoności"43.

Tak rozumiane świadectwo przekracza językowe struktury, systemy i porządek informacji. W jego wypadku przestaje być ważna tematyzacja myśli. Nieskończoność-absolut przekracza systemy i struktury, oddziela się w świadectwie od języka. Ważny okazuje się nie konkretny przekaz, ale samo głoszenie jej chwały. Nieskończoności nie może dosięgnąć żaden temat, żadna teraźniejszość czy obecność. W „oto jestem” nie ważna jest spójność, treść czy chronologia. Tym co ważne, obok autoafirmacji nieskończoności, jest tkwiące $\mathrm{w}$ świadectwie wezwanie do otwarcia na innego, bliskości, odpowiedzialności. Świadectwo okazuje się przestrzenią toż-samości i przykazaniem rozbrzmiewającym w ustach świadka. Oto „nieskończoność roztacza swoją chwałę w podmiocie, który dzięki niej się ukazuje i który ją głosi" ${ }^{44}$. W wypadku świadectwa otwartego na „dziejącą się" w nim rzeczywistość nieskończoności, mówienie okazuje

41 Ibidem, s. 444-445.

42 K. Tarnowski, Podmiot jako świadek, s. 23.

43 E. Levinas, Inaczej niż być lub ponad istota, tłum. P. Mrówczyński, Aletheia, Warszawa 2000, s. 245.

44 Ibidem, s. 248. 
się w sposób oczywisty szczerością i prawdomównością zbliżającą ja do innego ${ }^{45}$.

Choć ukryte w świadectwie hasło "oto jestem” odnosi się ostatecznie do Boga i głoszone jest w Jego imię, równocześnie brak w nim bezpośrednich odwołań do Jego obecności. Świadectwo, w którym odsłania się nieskończoność, w którego szczerości roztacza się jej chwała, opiera się na służbie innym, pokorze, wdzięczności, szczerości. Nieskończoność nie jest obecna jako temat świadectwa, nie odkrywa się też samemu świadkowi, pozostając niejako poza jego zasięgiem, ale poleca mu bliźniego - wydaje mu rozkaz i nakazuje posłuszeństwo, a następnie manifestuje się $\mathrm{w}$ jego postawie. W świadectwie mówienie staje się dawanym drugiemu znakiem braterstwa, bliskości i „współwiny bez powodu”. Wychodząca od własnej traumy, cierpienia i krzywdy podmiotowość zostaje wezwana przez nieskończoność i wychodzi poza siebie, ku drugiemu. Czynność mówienia staje się odpowiedzialnością - w levinasowskim świadectwie kryje się bezmiar odpowiedzialności, której tajemniczym nakazodawcą jest nieskończonośćc ${ }^{46}$. Sens świadectwa objawia się w tej myśli w pełni dopiero w odniesieniu do moralności - nieskończoność wzywająca i wybierająca konkretny podmiot na świadka odsyła go w sferę etyczną - ku drugiemu człowiekowi, a sama działa przez jego ręce. Bóg - nieskończoność, absolutnie inny, trzeci umożliwia pełne upodmiotowienie, które dokonuje się ostatecznie właśnie w przejściu ku drugiemu człowiekowi ${ }^{47}$.

Tischner zauważa, że myślenie według świadectwa stanowi integralny składnik całego myślenia religijnego i w związku z tym odgrywa niebagatelną rolę w tradycji religijnej. Kategorię wiary-fides interpretuje nie tylko jako „wiarę w coś”, ale także jako fidelitas - wierność wobec kogoś, następstwo towarzyszącego świadectwu aktu zawierzenia. Wierność okazuje się $\mathrm{w}$ tym miejscu formułą wzajemności możliwej w oparciu o „prawdę człowieka”, zachowującą swoje znaczenie także w sytuacjach świadectw składanych drugim, w oderwaniu od wymiaru religijnego. Zawierzenie, z którym łączy się w myśli Tischnera świadectwo, jest dla człowieka naturalne, stanowi realizację ludzkich dążeń i możliwości, urzeczywistnienie idei rozumności ${ }^{48}$. Akt zawierzenia rodzi się , ,jako więź swoista i samoistna, łącząca człowieka z człowiekiem, oparta na intuicji prawdy człowieka, jego wiarygodności" ${ }^{49}$. Doświadczenie drugiego $\mathrm{w}$ jego prawdzie otwiera na zawierzenie. Wraz z nim rodzi się intuicja, że drugi jest godny zaufania, jako ten, kto mówiąc powierza od-

\footnotetext{
45 Ibidem.

46 Ibidem, s. 250-255.

47 K. Tarnowski, Podmiot jako świadek, s. 22.

48 J. Tischner, Myślenie według wartości, s. 347-348.

49 Ibidem, s. 350.
} 
biorcy, niezależnie od treści komunikatu, samego siebie. Podobnie słuchacz, przyjmując jego słowa, powierza mu siebie - wówczas ich los się łączy, stają się uczestnikami jednego dramatu, włączonymi w łańcuch dziejowych zawierzeń ${ }^{50}$.

Zakorzeniona w porządku religijnym kategoria świadectwa nie daje się do niego całkowicie sprowadzić. Pierwotny wymiar świadectwa, pochodzący od Boga, absolutu czy absolutnego świadka - wezwanie i nakaz afirmacji - stanowią źródło imperatywu świadczenia, nakazującego podmiotowi nie tylko wierność wzywającej go rzeczywistości nadprzyrodzonej, lecz także wierność samemu sobie i wyjście ku innym. Świadek okazuje się odpowiedzialny zarazem przed absolutem, samym sobą jak i przed innymi ludźmi i za nich. Dzięki przejściu od rozumienia świadka przede wszystkim jako mającego kontakt z rzeczywistością transcendentalną świadka religijnego do odpowiedzialnego świadka etycznego, dodatkowe umocowanie zyskuje społeczny wymiar świadectwa. Otwarcie na wymiar nadprzyrodzony, poszukiwanie prawdy i sensu, łączą się z zarysowaną wcześniej w odniesieniu do świadectwa kategorią nadziei. Analizując przywołane powyżej koncepcje świadectwa, widzimy świadka nie jako mistyka czy męczennika, ale przede wszystkim po raz kolejny jako podmiot wezwany do odpowiedzialności, przyjmujący ją na siebie, poszukujący własnej godności oraz prawdy i wykazujący w tym poszukiwaniu inicjatywę, rozumiejący własną więź z innymi ludźmi, sprawczy i zaangażowany, zdolny do włączenia się w dziejową misję i „łańcuch zawierzeń".

\section{Świadectwo i doświadczenie}

Doniosłym i trudnym do rozwiązania problemem jest - uznawany za kluczowy dla świadectwa - jego związek z doświadczeniem. Z jednej strony oczywiste jest, że świadek odpowiedzialny, moralny i krytyczny, posiadający unikalną, niedostępną dla innych wiedzę, musiał ją wcześniej nabyć - właśnie na drodze doświadczenia. Z drugiej natomiast okazuje się, że mamy do czynienia z rzeczywistością znacznie bardziej skomplikowaną - mówiąc o „erze świadectwa”, odnosząc kategorie świadczenia do porządku historii, dochodzimy do oczekiwań, których świadek nie może spełnić. Trudno o bezpośrednich świadków radykalnego zła, największych zbrodni. Jak się wydaje, trudno jest także oczekiwać dawania świadectwa od ludzi głęboko skrzywdzonych, dotkniętych trauma, poranionych. W myśleniu o moralnym wymiarze świadectwa pojawia się pewna niespójność, wymagająca przyjrzenia się jego wewnętrznemu związkowi z doświadczeniem.

50 Ibidem, s. 348-352. 
Tischner na początku pierwszego rozdziału Filozofii dramatu, analizując budowę słowa doświadczenie zauważa, że jest ono złożone z dwóch elementów: do- i świadczenie, które wspólnie oznaczać mają dochodzenie do świadectwa. Etymologia słowa prowadzi autora do wniosku, że dane jest człowiekowi jedno tylko doświadczenie w pełnym znaczeniu - doświadczenie innego, spotkanie z nim, umożliwiające dialog oraz dawanie i przyjmowanie świadectwa. Spotkanie innego człowieka stanowi wydarzenie pociągające za sobą istotną zmianę w ludzkiej egzystencji, prowadzące do wyjścia ku drugiemu, transcendowania poza siebie: spotkanie jest tu zarówno wyjściem ku temu, kto może dawać świadectwo, jak i ku temu, przed którym można świadectwo złożyćc1. Tym samym, choć w samej Filozofii dramatu świadectwu poświęcone jest niewiele miejsca, okazuje się ono kategorią niezwykle ważną, na którym implicite nabudowana jest tischnerowska dialogiczna koncepcja człowieka jako istoty dramatycznej.

Derrida zauważa, że na poziomie etymologicznym widać tajemniczy związek świadectwa ze śmiercią - łacińskie testimonium (i pochodzące od niego słowa w językach europejskich) są zaskakująco bliskie testamentum. Śmierć, a także możliwość bycia od niej ocalonym (survivre, surviving), są zdaniem autora wplecione w rzeczywistość świadectwa. Językowe analizy związanych ze świadectwem terminów pozwalają Derridzie określać świadka jako obecnego, ocalonego (tertis - a więc trzeci, nie winowajca i nie bezpośrednia ofiara) i badającego, poddającego próbie (testis) $)^{52}$. Ważną właściwością świadka okazuje się obecność zarówno "teraz”, w chwili dawania świadectwa, składania zeznań czy poddawania próbie, jak i "wtedy", gdy miały miejsce wydarzenia, o których świadek mówi. Przedmiot świadectwa pozostaje dla świadka stale obecny - świadek nie tylko miał w przeszłości, ale i w pewien sposób ciaggle ma do niego dostęp. Chce, by o minionych wydarzeniach usłyszeli inni, dlatego szczerze i z zaangażowaniem, w dobrej wierze potwierdza, że to, o czym mówi, było prawdziwe, a on sam mówi prawdę. Świadek nie ma mocy dawania innym pewności, nie dostarcza dowodów, a jedynie deklaruje oraz pokazuje, że przedmiot świadectwa był dla niego ważny i że nadal taki jest. Jego deklaracje, szczerość, zaangażowanie i prośby, aby odbiorcy mu uwierzyli odnoszą się do porządku relacji, któremu bliskie są kategorie szczerości, zaufania czy obietnicy, nie do porządku teoretyczno-epistemicznego. Świadectwo nie wiąże się z pewnością ani z wiedza, umożliwia jedynie podzielenie się osobistym doświadczeniem. „Zaświadczam” rozumieć należy nie jako „udowad-

51 J. Tischner, Filozofia dramatu, Editions du dialogue, Paris 1990, s. 27.

52 J. Derrida, Poetics and Politics of Witnessing, w: idem, Sovereignties in Question: The Poetics of Paul Celan, red. T. Dutoit, O. Pasanen, Fordham University Press, New York 2005, s. 72-75. 
niam”, ale jako „przysięgam, że byłem obecny, czułem, widziałem, dotykałem..."

Analizy świadectwa zawarte w tekście Polityka i poetyka świadczenia Derrida osnuwa wokół wiersza Paula Celana Aschenglorie, w szczególności słów „nikt nie zaświadczy za świadka” ${ }^{54}$. Sam wiersz uznaje zarówno za świadka, jak i poetyckie świadectwo, wchodzące na zarazem możliwy i niemożliwy do osiągnięcia poziom meta-świadectwa. Sam fakt świadczenia i towarzyszącej mu obecności i samozwrotności okazuje się w wypadku wiersza istotniejszy niż tajemnicza treść świadectwa. Odnosząc się do cytowanych słów, Derrida stwierdza, że nikt nie może zaświadczyć za świadka, zarówno dlatego, że nikt tego uczynić nie potrafi, jak i dlatego, że nikt tego robić nie powinien. Świadectwo winno pozostać w sposób konieczny osobiste, oparte na indywidualnym doświadczeniu, przypisane do jednego konkretnego podmiotu, dysponującego unikalnym doświadczeniem. Jako takie nie może mieć pośredników czy łączników, pozostaje też nieprzetłumaczalne, opiera się testowi tłumaczenia ${ }^{55}$. Na gruncie kultury polskiej czytelnym tekstem kultury mówiącym o dawaniu świadectwa, który można przyrównać do wiersza-świadka Celana jest Przestanie Pana Cogito Zbigniewa Herberta. W wierszu, będącym poetyckim kategorycznym moralnym kodeksem pojawiają się słowa „ocalałeś nie po to, aby żyć/ Masz mało czasu, trzeba dać świadectwo" ${ }^{\prime \prime 6}$. Dawanie świadectwa to jeden z obowiązków wymienionych w stanowiącym swoisty dekalog, nawołującym do heroizmu tekście. Obowiązek dawania świadectwa okazuje się w wierszu głównym celem, jest ważniejszy od życia. Wezwanie do dawania świadectwa skierowane zostaje do ocalałego, doświadczonego, do kogoś, kto - gdyby wypadki potoczyły się inaczej - mógłby zostać jednym ze „zdradzonych o świcie”.

Problematyczna kwestia ugruntowania szczególnego autorytetu świadka na doświadczeniu, wydaje się przynajmniej częściowo związaną z faktem "ocalenia” świadka, możliwością bycia "trzecim” (tertis). W rzeczywistości świadectwa widać tu niespójność - jeśli ma ono dotyczyć - jak nierzadko zwykło się twierdzić w etyce - największych zbrodni, wówczas brak jest ich ofiar - jedynych bezpośrednich świadków, którzy mogliby o nich opowiedzieć. Derrida pisze w tym kontekście, że popiół (autor odwołuje się w tym miejscu do utworu Celana) anihiluje

53 Ibidem, s. 66-78.

54 "No one bears witness for the witness", tłum. M.P. (Za: J. Derrida, Poetics and Politics of Witnessing, s. 67).

55 Ibidem, s. 69-70.

56 Z. Herbert, Przestanie Pana Cogito, w: idem Wiersze zebrane, Czytelnik, Warszawa 1982, s. 256. 
bądź grozi anihilacją samej możliwości bycia świadkiem anihilacji ${ }^{57}$. Hiperbolizując podobne stwierdzenia, Lyotard pisze, że człowiek martwy nie może zaświadczyć o tym, że nie żyje właśnie z powodu istnienia komory gazowej ${ }^{58}$.

W koncepcji Lyotarda świadectwo miałoby dotyczyć tego, co nieprezentowalne -trudne do wypowiedzenia i pojęcia, przemilczane ${ }^{59}$. Zdaniem Margalita, specyficzny autorytet moralnego świadka wynikać miałby właśnie ze zdolności do opisania tego, czego nie sposób nazwać i opisać, z umiejętności przekazania doświadczenia radykalnego zła. Ten, kto go doświadczył i przeżył, staje się wiarygodnym świadkiem, który może nie tylko opisać, co się stało, nie tylko dokonać słusznej oceny moralnej opisywanych wydarzeń, lecz także realnie oddziaływać na odbiorców. Autorytet świadka moralnego wiąże się także ze szczerością, spójnością przekazu i emocji i autentycznością - pozbyciem się wszelkich personae, masek $\mathrm{i}$ wyrażaniu prawdziwego siebie ${ }^{60}$. Jest tu miejsce także dla świadka słabego, cierpiącego, widocznie skrzywdzonego; także taki świadek może mieć wpływ na innych.

Możliwość świadczenia o swoich losach w sposób konieczny zakłada znajomość własnych przeżyć, wspomnień i stanów mentalnych. Nie można być, zdaniem Margalita, zastępczym świadkiem moralnym poprzez wczucie się $\mathrm{w}$ historię bezpośredniego świadka, poznanie jego losów, wierne bądź po prostu niezwykle wiarygodne i przejmujące odtworzenie historii. Autentyczność pierwszoosobowego doświadczenia jest obiektywna i nie da się jej zastąpić siłą perswazji ani procesem emocjonalnym, nie może się też z nią równać obserwacja danego wydarzenia ${ }^{61}$. Margalit uznaje, że $w$ wypadku świadectwa właściwa ocena opisywanych wydarzeń bywa ważniejsza od płaszczyzny faktograficznej - oczekuje się od niego prawdziwości, ale nie ocenia według historycznych standardów, dopuszczając zawodność pamięci dającego świadectwo. Świadek ponosi natomiast moralną odpowiedzialność za przekazanie prawdy bez nadużyć, niedomówień i manipulacji ${ }^{62}$.

O świadkach moralnych, w odwołaniu do Margalita, pisze historyk Winter. Świadków takich uznaje za szczególną kategorię „opowiadaczy", dzielących się osobistym, bezpośrednim doświadczeniem radykalnego zła. Moralni świadkowie to ludzie odczuwający moralny gniew, oburzenie, frustrację, sprzeciwiający się kłamstwom i manipulacjom, dą-

57 Ibidem, s. 68.

58 J.-F. Lyotard, The Differend, s. 3-4; zob. T. Majewski, Świadectwo-pomiędzy wnętrzem i zewnętrzem języka, "Teksty Drugie" nr 5 2007, s. 77.

59 Bearing witness, w: The Lyotard Dictionary, red. S. Sim, Edinburgh University Press., Edinburgh 2011, s. 27.

60 A. Margalit, The Ethics of Memory, s. 168-170.

61 Ibidem, s. 172-175.

62 Ibidem, s. 165. 
żący do oczyszczenia od nich przeszłości. Podjęcie przez nich opowieści to reakcja na osobiste doświadczenie radykalnego zła. Pamięć o złu jest w ich wypadku koniecznościa, nie tylko wyborem czy potrzebą. Doświadczeni uprzednio świadkowie stają się częścią "archiwum” i stają na straży pamięci, domagają się jej respektowania. Prośba świadków o wysłuchanie i włączenie ich opowieści do aktywnej wiedzy okazuje się zdaniem Wintera podstawowym powodem zobowiązania współczesnych do pamięci ${ }^{63}$.

W myśli Lyotarda dawanie świadectwa - integralna część postmodernistycznej świadomości - ma obligującą moc. Bycie świadkiem związane jest z zajmowaniem stanowiska, opowiadaniem się po właściwej stronie - w tym wypadku opowiadaniem się przeciw wybielającym historię, posługującymi się manipulacją i przemilczeniami wielkiej narracji i dominującym ideologiom. Świadectwo mówiące o tym, co nieprezentowalne, a tym samym pomijane $\mathrm{w}$ dominujących narracjach i ideologiach, jest zawsze świadectwem przeciwko narzucanym interpretacjom i wersjom historii. Dawanie świadectwa o nieprezentowalnym - o tym, co ukrywane, pozostające poza naszą wiedzą i wpływem - jest odmową uczestnictwa w zbiorowej narracji i udaremnieniem jej celów, przywoływaniem innym tego, o czym (za sprawą dominującej narracji) mieliby zapomniećct ${ }^{4} \mathrm{O}$ „zajmowaniu stanowiska” pisze też Robert M. Adams, według którego świadectwo dotyczące szczególnie ważnych kwestii moralnych bądź religijnych, nie pozostaje nigdy suchym świadectwem o czymś, zawsze staje się zarazem świadectwem „za czymś” bądź „przeciw czemuś”, towarzyszy mu symboliczne wyznanie miłości do dobra bądź nienawiści do zła. Świadectwo będące sprzeciwem wobec ludzkiej krzywdy i cierpienia staje się kontrprzesłaniem wobec zadających cierpienie. Świadczenie o cierpieniu ofiar, zdegradowanych przez wyrządzoną krzywdę, jest drogą do przywrócenia im pozycji w zbiorowości, potwierdzenia ich moralnego statusu, a co za tym idzie, przywrócenia porządku moralnego, właściwego postrzegania dobra i zła ${ }^{65}$.

Niezwykle trafna wydaje się metafora głosu (bądź też odwrotnie milczenia), która pojawia się w kontekście świadectwa w pracach różnych autorów. Tarnowski pisze, że wydarzenie jest pod względem swej prawdy zdane na świadka, inaczej pozostałoby nieme ${ }^{66}$. Świadek uprzywilejowany, odpowiedzialny i zaangażowany przedstawiciel pamięci staje się po prostu jej głosem, jedynym, jaki ma szansę wybrzmieć. Podobnie Blustein wielokrotnie posługuje się metaforą głosu - pisze o jego zabieraniu, oddawaniu go innym, byciu przywoływanym. Głoszenie

63 J. Winter, The moral witness and the two world wars, s. 467-468.

64 Bearing witness, w: The Lyotard, Dictionary, s. 27-28.

65 Za: J. Blustein, The Moral Demands of Memory, s. 331-334.

66 Tarnowski, Wiara-sens-świadectwo, w: idem, Wiara i myślenie, s. 60. 
świadectwa jest przełamywaniem nastałej wokół wydarzeń z przeszłości ciszy, milczenia. Często ma ono postać zabierania głosu w zastępstwie kogoś, komu głos, często brutalnie, odebrano bądź kto sam jest zbyt słaby, bezradny, czy pełen bólu, by móc dzielić się swoim doświadczeniem i wypowiadać własne racje. Zabranie głosu w jego imieniu umożliwia przerwanie narastającej wokół krzywdy ciszy i stanowi ostateczne zerwanie ze złem - tak złem krzywdy czy przemocy, jak i wtórnym złem milczenia. Odmawianie komuś głosu jest natomiast swoistą uzurpacją w której nie bierze się pod uwagę czyichś doświadczeń, interesów i punktu widzenia, jest podważeniem jego ważności i wiarygodności, a zarazem próbą narzucenia zbiorowości własnej narracji. Jeśli ofiary nie ma, bądź sama nie może zabrać głosu, powinien pojawić się zdaniem Blusteina jej pełnomocnik - ktoś bliski emocjonalnie - po to, aby zapobiec (lub przynajmniej spróbować zapobiec) bagatelizacji, trywializacji i zapomnieniu zła, opowiedzieć się po właściwej stronie i, zabierając głos $\mathrm{w}$ zastępstwie ofiary, przywołać jej doświadczenia ${ }^{67}$. Metafora zabierania głosu w zastępstwie ofiar, rozwiązuje częściowo przynajmniej problem doświadczenia w kontekście największego zła. Zabierający głos, przywołujący głos ofiary bliski człowiek nie zawłaszcza jej dramatu, nie odbiera świadectwa, nie podszywa się pod nią, a jedynie przerywa milczenie, przywracając jej perspektywę, stając w jej obronie.

\section{Prawda i świadectwo}

W dyskusji o związku świadectwa z doświadczeniem pojawia się problem prawdy świadectwa, pewnego rozdźwięku między jego prawdziwością a autentycznością. Wydaje się, że problem prawdy i prawdziwości świadectwa wymaga dodatkowych analiz i przywołania myśli autorów, dla których wymiar prawdziwościowy byłby podstawowy dla rzeczywistości świadczenia. W kontekście dyskusji o świadku domagająca się afirmacji kategoria prawdy wiąże się ostatecznie z ludzką wolnością, okazuje się powinnościorodna i pociąga za sobą daleko idące moralne konsekwencje.

Najważniejszym elementem świadectwa w koncepcji Marcela jest poświadczenie: stwierdzenie i potwierdzenie, w którym podmiot z zupełną swobodą wiąże samego siebie. Świadectwo w sposób konieczny jest wolne, realizujące najintymniejszy i najbardziej tajemniczy związek z wolnością - dokonane pod przymusem stanowiłoby swoje własne zaprzeczenie. Poświadczając podmiot deklaruje, że gdyby rzeczywistości o której świadczy zaprzeczył, wówczas zaprzeczyłby również sam sobie,

67 J. Blustein, The Moral Demands of Memory, s. 344-345. 
samego siebie unieważnił ${ }^{68}$. W myśli Ricoeura rzeczywistość świadectwa okazuje się dwubiegunowa, wymiar narracyjny spleciony zostaje z wyznaniem i towarzyszącą mu afirmacją, natomiast fakt - z sensem ${ }^{69}$. Fałszywe świadectwo, powszechnie postrzegane jako szczególnie naganne, autor nazywa „kłamstwem w sercu świadka”, o autentycznym świadectwie pisze natomiast jako o „przypieczętowaniu swej wierności sprawie $^{\prime \prime 70}$. Świadek wierność sprawie deklaruje publicznie, a w obronie prawdy wykazuje gorliwość, oddanie, gotowość poświęcenia. Powiązane z ludzką wewnętrznością, dotykające sumienia świadectwo jest $\mathrm{w}$ takim rozumieniu „zaangażowaniem czystego serca”, a świadek - człowiekiem, który utożsamiwszy się ze słuszną sprawą jest gotów nawet narazić dla niej życie ${ }^{71}$.

Tischner pisze o wiarygodnym świadku, którym jest partner dialogu, a przede wszystkim „uczestnik tego samego dramatu, w którym ja sam biorę udział"72. Świadek to ktoś doświadczony, wystawiony na nieszczęścia, ale także ktoś, kto dokonał egzystencjalnej decyzji i uznał absolutny charakter zobowiązania przez prawdę o fakcie, o którym daje świadectwo. Zobowiązując się w wolności, świadek decyduje się na heroizm ${ }^{73}$. W myśli Tischnera pojawia się jeszcze jedna, specyficzna forma świadectwa - osobistego, dawanego własnym głosem, ręką i uczynkiem - kategoryczne i indywidualne poczucie obowiązku ${ }^{74}$. Cała moralność zyskuje $\mathrm{w}$ tym miejscu strukturę świadectwa, a ludzkie życie okazuje się "łańcuchem świadectw" w jeszcze innym rozumieniu - jako ciąg świadomych czynów, przez które podmiot świadczy o sobie.

Wiążąca kategorie świadectwa, prawdy i wolności intuicja pojawia się w myśli Stycznia - człowiek staje się świadkiem każdej prawdy, którą poznaje i uznaje, z którą sam się wiąże. Prawda w szczególny sposób człowieka wiąże, przyjęta $\mathrm{w}$ akcie poznania staje się moralnym imperatywem. Poznawszy ją automatycznie staje się on jej świadkiem, któremu nie wolno zaprzeczyć poznanej prawdzie - jej negowanie staje się zarazem sprzeniewierzeniem się samemu sobie, jako temu, kto wcześniej ją przyjął. Świadek sprzeniewierzający się prawdzie okazuje się równocześnie winowajca, sprawcą zdrady i jej ofiarą. Dostrzegając tę zdradę, niespójność w obrazie świata i siebie, staje się też zarazem własnym sędzią $^{75}$ W innym miejscu Styczeń odnosi się w podobnym kontekście

68 G. Marcel, Rozważania na temat wiary, s. 251.

69 P. Ricoeur, Hermeneutyka świadectwa, s. 30.

70 Ibidem, s. 24.

71 Ibidem, s. 24-25.

72 J. Tischner, Myślenie według wartości, s. 351.

73 Ibidem, s. 350-351.

74 Ibidem, s. 385.

75 T. Styczeń, Być sobq to przekraczać siebie - O antropologii Karola Wojtyły, w: K. Wojtyła, Osoba i czyn oraz inne studia antropologiczne, red. T. Styczeń, W. Chudy, J. Gałkowski, KUL, Lublin 2011, s. 493-494. 
do pewnego szczególnie barwnego, historycznie zakorzenionego przykładu - casusu więźnia politycznego, mogącego w Polsce lat 80. dwudziestego wieku opuścić więzienie po podpisaniu deklaracji lojalności. Ów więzień, zwany przez autora Kowalskim, przeżywa bardzo szybką i skuteczną „wstrząsającą lekcję etyki” - nagle rozumie, że nie wolno mu sprzeniewierzyć się samemu sobie i poznanej i uznanej prawdzie, tym samym nie wolno mu „lojalki” podpisywać, mimo ceny pozostania w więzieniu, jaką przyjdzie mu za akt odmowy zapłacić. Odkrywa, że za cenę fizycznej wolności nie może pozbawić się znacznie ważniejszej, prawdziwej wolności, a co się z tym wiąże - wierności wobec poznanej prawdy i wobec samego siebie. Kowalski odkrywa w sobie świadka prawdy, której - gdy ją poznał i stwierdził, nie wolno mu zaprzeczyćc ${ }^{76}$.

Tarnowski uznaje świadectwo dawane prawdzie za podstawowa, a zarazem wyjątkową postać świadectwa, mogąca w pewnej mierze powoływać podmiot do życia. Prawda - w ujęciu Tarnowskiego, każda prawda - jest tym, co podmiot mobilizuje bądź to jako cel poszukiwań, bądź jako rzeczywistość, z którą trzeba się liczyć. Materiałem świadectwa jest prawda niemożliwa do udowodnienia, ponadempiryczna, ponadnaukowa, związana $\mathrm{z}$ niepowtarzalnym, historycznym wydarzeniem, doniosła życiowo, ważna i zwalczana, domagająca się obrony. Świadectwo konkretnej prawdzie jest zawsze świadectwem dawanym prawdzie jako takiej, stanięciem po stronie prawdy w procesie mającym prowadzić do jej relatywizacji „w procesie, który toczy się w kulturze na naszych oczach"77. Świadectwo w swej istocie okazuje się obroną prawdy przed relatywizacją - zgoda na względność, nieistnienie prawdy, pociaggałaby za sobą stwierdzenie, że nie jest potrzebne żadne świadectwo. Świadectwo prawdy wykuwa się na dwóch poziomach: pierwszym, na którym prawda się komuś jawi, następuje "olśnienie”, a podmiot spontanicznie przyświadcza jej wewnętrznie i drugim, wymagającym decyzji i zaangażowania poziomie świadectwa sensu stricto. Przyświadczenie prawdzie ma miejsce w sytuacji intersubiektywnej, gdy staje się ona zagrożona, gdy „świadek wobec prawdy może i powinien stać się wtedy tym świadkiem prawdy wobec ludzi"78. Ten, kto decyduje się świadczyć chce być prawdomówny, przezroczysty dla prawdy, z którą utożsamia własną wartość, podmiotowe „ja aksjologiczne", tak dalece, że świadectwo o prawdzie staje się zarazem świadectwem o nim samym. Świadek prawdy gotowy do jej świadczenia wokół niej organizuje swoją podmiotowość ${ }^{79}$. Jest odpowiedzialny za treść swojego świa-

${ }^{76}$ T. Styczeń, Wolność w prawdzie, Fundacja Jana Pawła II, Polski Instytut Kultury Chrześcijańskiej, Rzym 1988, s. 13.

77 K. Tarnowski, Podmiot jako świadek, s. 29-30.

78 Ibidem, s. 30-31.

79 Ibidem, s. 31-32. 
dectwa, ręczy za nią samym sobą. W jego prawdomówności łączy się to, co mówi i to, jaki jest, a treść świadectwa weryfikowana jest sposobem bycia świadka. Jeśli jego słowa i czyny się rozmina, wówczas świadectwo okaże się fałszywe. Podmiot poruszony przez prawdę i rzeczywistość zostaje obudzony, wezwany. Na wezwanie rzeczywistości odpowiada, by następnie przejąć odpowiedzialność za siebie, prawdę i drugiego ${ }^{80}$.

\section{Uwagi końcowe}

Z przedstawionych analiz wyłania się postać świadka zaangażowanego moralnie - podmiotu silnego, sprawczego i odpowiedzialnego, świadomego swej sprawczości i odpowiedzialności. Świadek, który decyduje się przyjąć imperatyw świadczenia - bohater współczesności, przedstawiciel pamięci, podmiot doświadczony i kompetentny - mimo przeżytego cierpienia pozostaje otwarty na innych i pełen specyficznej nadziei. Nie traci wiary $w$ sens świadczenia, nie wattpi w prawdę, nie popada w bierność. Zaangażowanie świadka widać w całym procesie świadczenia. Świadomie zachowuje on treść świadectwa w pamięci, stara się posiąść wiedzę na temat opisywanych wydarzeń, dokonuje ich moralnej oceny, inicjuje sytuację świadczenia. Zabiera głos w ważnej sprawie, $\mathrm{w}$ obronie prawdy bądź w obronie innych. Kolejne podjęte w tekście kroki: zarysowanie zaangażowania $\mathrm{w}$ sytuacji świadectwa, ukazanie przejścia od religijnego do etycznego wymiaru świadectwa i przedstawienie jego związków z doświadczeniem i prawda, pozwoliły ukazać istotne własności świadka: jego aktywność w procesie dawania świadectwa, zdolność transcendowania siebie i poszukiwania prawdy, umiejętność radzenia sobie z trudnymi doświadczeniami i gotowość bronienia innych, wreszcie - gotowość do „wiązania się” prawdą i poświęcenia dla niej.

\section{Bibliografia}

Bearing witness, w: The Lyotard Dictionary, red. Sim S., Edinburgh 2011.

Blustein J., The Moral Demands of Memory, New York 2008.

Coady C. A. J., Testimony: A Philosophical Study, New York 1992.

Derrida J., Poetics and Politics of Witnessing, w: idem, Sovereignties in Question: The Poetics of Paul Celan, red. Dutoit T., Pasanen O., New York 2005.

Felman S., In an Era of Testimony: Claude Lanzmann's Shoah, "Yale French Studies" 79 (1991).

\footnotetext{
80 Ibidem, s. 18-20.
} 
Frish A., The Ethics of Testimony: A Geneological Perspective, „Discourse” 25.1\&2 (2003) .

Gadacz T., Historia filozofii XX wieku, T. 1, Kraków 2009.

Herbert Z., Przestanie Pana Cogito, w: idem Wiersze zebrane, Warszawa 1982.

Levinas E., Inaczej niż być lub ponad istota, przeł. Mrówczyński P., Warszawa 2000.

Lyotard J.-F., The Differend: Phrases in Dispute, przeł. Van Den Abbeele G., Mineapolis 2002.

Majewski T., Świadectwo-pomiędzy wnętrzem i zewnętrzem języka, „Teksty drugie" nr 52007.

Marcel, Dziennik metafizyczny w: idem, Być i mieć, przeł. Lubicz P., Warszawa 1962.

Marcel G., Rozważania na temat wiary, w: idem, Być i mieć, przeł. Lubicz P., Warszawa 1962.

Marcel G., Zarys fenomenologii posiadania, w: idem, Być i mieć, przeł. Lubicz P., Warszawa 1962.

Margalit A., The Ethics of Memory, Cambridge 2004.

Ricoeur P., Hermeneutyka świadectwa, w: Nazwać Boga. Teksty Paula Ricoeura, red. Grzywacz R., przeł. Grzywacz R., Kraków 2011.

Tarnowski K., Podmiot jako świadek, w: idem, Wiara i myślenie, Kraków 1999.

Tarnowski K., Wiara-sens-świadectwo, w: idem, Wiara i myślenie, Kraków 1999.

Tarnowski K., W poszukiwaniu absolutnego Świadka, w: idem, Wiara i myślenie, Kraków 1999.

Tischner J., Filozofia dramatu, Paris 1990.

Tischner J., Myślenie według wartości, Kraków 1981.

Styczeń T., Być soba to przekraczać siebie - O antropologii Karola Wojtyły, w:

Wojtyła K., Osoba i czyn oraz inne studia antropologiczne, red. Styczeń T., Chudy W., Gałkowski J., Lublin 2011.

Styczeń T., Wolność w prawdzie, Rzym 1988.

Wieviorka A., The Era of the Witness, przeł. Stark J., New York 2006.

Winter J., The "moral witness" and the two world wars, "Ethnologie française", XXXVII, 2007.

\section{Głos nadziei w "erze świadectwa”. Kategoria świadka w dyskusji etycznej}

\section{Słowa kluczowe}

Świadek; świadectwo; dawanie świadectwa; moralność; doświadczenie; prawda

Rzeczywistość świadectwa jest doniosła, dobrze znana, obecna w wielu sytuacjach i kontekstach ludzkiego życia. Kategorie świadka i świadectwa są obecnie cenione i eksponowane w społecznym dyskursie. Stanowią także przedmiot filozoficznej refleksji - we współczesnej myśli autorów należących do różnych 
tradycji i szkół filozoficznych warto zwrócić uwagę na koncepcje świadectwa i świadka, w których szczególnie istotny jest wymiar moralny. W takich ujęciach (np. w myśli Margalita, Blusteina, Tarnowskiego) świadek, któremu przysługuje autorytet, przekazuje odbiorcom treść swojego osobistego, często trudnego i bolesnego doświadczenia, dokonując przy tym moralnej oceny wydarzeń, kształtując odbiorców i wpływając na zbiorową pamięć. Działa z pobudek moralnych, jest krytyczny i odpowiedzialny. Jego świadectwu towarzyszy opowiedzenie się po stronie dobra. Swiadek „zabiera głos” w obronie słabych i pokrzywdzonych (pisze o tym Blustein), a (jak pisze Margalit) w pewnym szczególnym sensie towarzyszy mu nadzieja. Imperatyw dawania świadectwa bywa przez filozofów (Marcela, Naberta, Levinasa, Tischnera) łączony z porządkiem religijnym. W sposób szczególny oczekuje się świadectwa o wydarzeniach najważniejszych - w tym o doświadczeniu radykalnego zła. To oczekiwanie wprowadza $\mathrm{w}$ rozumienie świadectwa element niespójności - w wypadku największych zbrodni trudno o bezpośrednich świadków (wątek ten wyraźny jest w myśli Derridy). Specyficzny moralny autorytet świadka wynika właśnie z bezpośredniego doświadczenia, pierwszoosobowej perspektywy, autentyczności i wiarygodności. Autorzy (Marcel, Tischner, Tarnowski, Styczeń) podkreślają związek świadectwa z prawdą - poznający prawdę świadek decyduje się ją afirmować, angażując i wiążąc swoją wolność. Interesujący z punktu widzenia etyki świadek okazuje się podmiotem silnym, sprawczym, świadomym i zaangażowanym.

\section{The voice of hope in the "testimony era". The category of witness in ethical discourse}

\section{Keywords}

Witness; testimony; bearing witness; morality; experience; truth

The reality of testimony is momentous, well known, present in many situations and contexts of human life. The categories of witness and testimony are currently appreciated and emphasized in social discourse. They are also the subject of philosophical discourse; in the contemporary thought of authors belonging to various philosophical traditions and schools it is worthwhile to pay attention to the concepts of testimony and witness, in which moral dimension is particularly essential. In such perspective (e.g. in the thought of Margalit, Blustein, and Tarnowski) a witness, who is vested with authority, transfers the content of his or her personal, often difficult and painful experience to the audience, while making a moral assessment of events, shaping the audience and influencing the collective memory. Witnesses act for moral reasons, are critical and responsible. Their testimony is accompanied by speaking in favour of good. The witness "speaks" in defence of the weak and the disadvantaged (Blustein writes about that) and (as writes Margalit), in certain particular sense, is accompanied by hope. The imperative to give testimony is sometimes connected by philosophers with a religious order (Marcel, Nabert, Levinas, Tischner). In particular, the testimony of the most important events is expected, including the experience of radical evil. 
That expectation introduced an element of inconsistency to the understanding of testimony; in the case of the greatest crimes it is difficult to find direct witnesses (this motive is clear in Derrida's thought). A specific moral authority of a witness results just from direct experience, the first person perspective, authenticity and credibility. The authors (Marcel, Tischner, Tarnowski, Styczeń) emphasize the relationship between testimony and truth; a witness getting to know the truth decides to affirm it, while engaging and binding his or her freedom. The witness, interesting from the point of view of ethics, turns out to be a strong, causative, aware and involved subject. 